\title{
Kualitas Mikrobiologis Susu Kambing dengan Metode Pasteurisasi High Temperature Short Time (HTST) pada Penyimpanan Berbeda
}

\author{
Microbiological Quality of Goat Milk with High Temperature Short Time (HTST) Pasteurization Method in \\ Different Storage
}

V. Wanniatie*, A. Qisthon, A. Husni, \& E. Olsen

Department of Animal Husbandry, Faculty of Agriculture, University of Lampung, Bandar Lampung

Jl. Prof. Dr. Sumatri Brojonegoro No 1 Gedung Meneng, Bandar Lampung, Indonesia

*Corresponding author: veronica.wanniatie@fp.unila.ac.id

(Received 28-11-2020; Revised 19-12-2020; Accepted 21-01-2021)

\begin{abstract}
The aim of this study was to determine the effectiveness of the pasteurization method on the microbiological quality of goat's milk stored at different times in the refrigerator. The research was conducted in MarchMay 2020 at the Animal Production Laboratory of the University of Lampung and the Laboratory of the Lampung Veterinary Center. The goat milk sample were colleted from Etawah Grade goats from smallholder farms in Metro City. Milk samples were taken from 20 goats from Etawah Grade in the $2 \mathrm{nd}$ and 3rd lactation periods. The goat milk sample used was 9 liters. Goat milk samples were pasteurized using the high temperature short time (HTST) method at a temperature of $72^{\circ} \mathrm{C}$ for 15 seconds then cooled and put in a plastic bottle and stored in the refrigerator. This study used a completely randomized design (CRD) with long storage treatment (0 days, 12 days, 24 days, 36 days, 48 days, and 60 days) in the refrigerator. The results showed that pasteurized goat milk with different storage times had no effect on the microbiological quality, namely TPC, $S$. aureus, coliform bacteria, $E$. coli, reductase numbers and pH values. The conclusion of this study is that pasteurized goat's milk using the HTST method is still suitable for consumption until the 60th storage day.
\end{abstract}

Keywords: bacteria, goat milk, pasteurized, reduktase, refrigerator

\begin{abstract}
ABSTRAK
Tujuan penelitian ini adalah untuk mengetahui efektivitas metode pasteurisasi terhadap kualitas mikrobiologis susu kambing yang disimpan dengan waktu yang berbeda didalam refrigerator. Penelitian dilaksanakan pada bulan Maret-Mei 2020 bertempat di Laboratorium Produksi Ternak, Universitas Lampung dan Laboratorium Balai Veteriner Lampung. Sampel susu kambing berasal dari kambing Peranakan Etawah dari peternakan rakyat di Kabupaten Metro. Sampel susu dikoleksi dari 20 ekor kambing Peranakan Etawah pada periode laktasi ke-2 dan ke-3. Sampel susu kambing yang digunakan sebanyak 9 liter. Sampel susu kambing di pasteurisasi dengan metode high temperature short time (HTST) dengan suhu $72^{\circ} \mathrm{C}$ selama 15 detik lalu didinginkan dan dimasukkan kedalam botol plastik dan disimpan pada refrigerator. Penelitian ini menggunakan Rancangan Acak Lengkap dengan perlakuan lama penyimpanan (0 hari, 12 hari, 24 hari, 36 hari, 48 hari, dan 60 hari) didalam refrigerator. Hasil penelitian menunjukkan bahwa susu kambing pasteurisasi dengan lama penyimpanan berbeda tidak berpengaruh terhadap kualitas mikrobiologi yaitu TPC, S. aureus, bakteri koliform, E. coli, angka reduktase dan nilai $\mathrm{pH}$. Kesimpulan dari penelitian ini adalah susu kambing yang dipasteurisasi dengan metode HTST masih layak dikonsumsi sampai penyimpanan hari ke-60.
\end{abstract}

Kata kunci: bakteri, pasteurisasi, reduktase, refrigerator, susu kambing 


\section{PENDAHULUAN}

Susu kambing sudah banyak dikonsumsi oleh masyarakat di Indonesia. Peningkatan jumlah konsumsi susu kambing menjadi peluang bagi peternak untuk membudidayakan ternak kambing perah. Kambing perah yang banyak dipelihara di Indonesia adalah jenis kambing Saanen, Etawah, Peranakan Etawah, Sapera, dan Jawa Randu karena memiliki produksi susu yang cukup tinggi. Pemeliharaan kambing perah relatif lebih mudah dibandingkan dengan sapi perah, dan harga jual susu kambing juga lebih mahal dibandingkan susu sapi perliternya, yaitu Rp 35 000-60 000 .

Susu dapat tercemar oleh bakteri patogen atau nonpatogen yang berasal dari ternak itu sendiri, peralatan pemerahan, ruang penyimpanan yang kurang bersih, debu, udara, lalat dan penanganan oleh manusia. Pertumbuhan mikroorganisme dalam susu dapat menurunkan mutu dan keamanan pangan susu, yang ditandai oleh perubahan rasa, aroma, warna, konsistensi, dan penampakan (Chotiah 2020).

Pemerintah Indonesia telah mengeluarkan undangundang nomor 7 tahun 1999 tentang keamanan pangan yaitu kondisi dan upaya yang diperlukan untuk mencegah pangan dari kemungkinan cemaran biologik (mikrobiologi), kimia, kimia toksik, dan benda-benda lain yang mengganggu, merugikan dan membahayakan kesehatan manusia. Pasteurisasi merupakan salah satu cara pemanasan susu yang bertujuan untuk mematikan mikroorganisme patogen, menurunkan jumlah mikroorganisme perusak, dan dapat menginaktifkan enzim (Walkling-Ribeiro et al. 2011).

Sebagian masyarakat Indonesia mengonsumsi susu kambing dalam kondisi mentah. Hal ini dikarenakan kepercayaan bahwa susu kambing segar memiliki khasiat lebih baik dibandingkan susu yang telah dimasak. Susu kambing segar mengandung cemaran mikroba (TPC), $S$. aureus, Enterobacteriaceae dan bakteri koliform yang dapat membahayakan konsumen (Wanniatie et al. 2019). Penelitian mengenai cara pencegahan pangan asal hewan yang mengandung mikroba yang dapat membahayakan kesehatan manusia perlu dilakukan, salah satunya adalah proses penanganan pengolahan susu melalui pasteurisasi dan penyimpanan yang baik sehingga susu kambing dapat bisa lama disimpan. Tujuan penelitian ini adalah mengetahui kualitas mikrobiologis baik secara langsung (TPC, S. aureus, bakteri koliform, dan E.coli) maupun tidak langsung (uji reduktase) susu kambing pasteurisasi dengan lama penyimpanan yang berbeda.

\section{MATERI DAN METODE}

Materi yang digunakan pada penelitian ini adalah susu kambing. Sampel susu kambing berasal dari satu peternakan rakyat yang berlokasi di Kota Metro, Provinsi Lampung. Sampel susu dikoleksi dari 20 ekor kambing Peranakan Etawah pada periode laktasi ke-2 dan ke-3 pada waktu pemerahan pagi hari. Sampel susu kambing yang digunakan pada penelitian ini adalah susu kandang yaitu susu yang sudah dicampur pada 1 kali pemerahan. Sampel susu kambing yang digunakan adalah sebanyak 9 liter dan di bawa dengan menggunakan cool box yang diberi es batu. Penelitian dilaksanakan pada bulan Maret-Mei 2020, berlokasi di Laboratorium Produksi Ternak Universitas Lampung dan Laboratorium Balai Veteriner Lampung.

\section{Prosedur Penelitian}

Sampel susu kambing dimasukkan kedalam botol steril ukuran $500 \mathrm{~mL}$ lalu di pasteurisasi dengan metode high temperature short time (HTST) dengan suhu $72{ }^{\circ} \mathrm{C}$ selama 15 detik. Susu kambing yang sudah di pasteurisasi lalu didinginkan dengan direndam air selama \pm 15 menit sampai suhu $\pm 40^{\circ} \mathrm{C}$. Sampel susu kambing lalu dimasukkan kedalam botol plastik yang tidak disterilkan yang berukuran $250 \mathrm{~mL}$. Sampel susu kambing pasteurisasi lalu disimpan didalam refrigerator dengan suhu $4-10{ }^{\circ} \mathrm{C}$ sampai waktu pengujian.

\section{Perhitungan Total plate count (TPC)}

Pengujian untuk menentukan angka lempeng total (Total Plate Count) berdasarkan SNI 01-2782-1998 (BSN 1998) yang mengacu pada Compendium of Methods for the Microbiological Examination of Food (1992). Perhitungan jumlah total mikroorganisme (TPC) dilakukan dengan metode hitungan cawan. Sampel susu pasteurisasi diambil $1 \mathrm{~mL}$ lalu diencerkan dengan larutan Buffered pepton water (BPW) $0.1 \%$ sampai dengan pengenceran $10^{-5}$. Selanjutnya pada masing-masing pengenceran diambil $1 \mathrm{~mL}$ kedalam cawan petri steril dan lalu dituang Plate Count Agar (PCA) cair dan dihomogenkan dengan cara menggeserkan cawan horizontal atau membentuk angka delapan. Agar dibiarkan membeku dan diinkubasi pada suhu $37^{\circ} \mathrm{C}$ selama 24 sampai dengan $48 \mathrm{jam}$. Semua koloni mikroorganisme yang tumbuh dihitung sebagai jumlah total mikroorganisme (TPC).

\section{Perhitungan Staphylococcus aureus}

Perhitungan S. aureus dilakukan berdasarkan SNI 012782-1998 (BSN 1998) yang mengacu pada Compendium of Methods for the Microbiological Examination of Food (1992). Perhitungan S. aureus dilakukan dengan metode hitungan cawan. Sampel susu pasteurisasi diambil $1 \mathrm{~mL}$ lalu diencerkan dengan larutan Buffered pepton water (BPW) $0.1 \%$ sampai dengan pengenceran $10^{-2}$. Selanjutnya $1 \mathrm{~mL}$ sampel susu tanpa pengenceran dan pengenceran $10^{-1}$ dan $10^{-2}$ dimasukkan kedalam cawan petri steril lalu dituang Baird Parker Agar (BPA) (tambahkan $5 \mathrm{~mL}$ egg yolk tellurite ke dalam $95 \mathrm{~mL}$ agar cair) cair dan dihomogenkan dengan cara menggeserkan cawan horizontal atau membentuk angka delapan. Agar dibiarkan membeku dan diinkubasi pada suhu $37{ }^{\circ} \mathrm{C}$ selam 24 sampai 48 jam. Semua koloni mikroorganisme yang tumbuh dihitung sebagai $S$. aureus.

\section{Perhitungan Koliform dan Escherichia coli}

Perhitungan koliform dan E. coli dilakukan berdasarkan SNI 01-2782-1998 (BSN 1998) yang mengacu pada Compendium of Methods for the Microbiological Examination of Food (1992). Perhitungan jumlah koliform dilakukan dengan metode hitungan cawan dengan cara tuang (pour plate methode). Sampel susu kambing diambil $1 \mathrm{~mL}$ dimasukkan kedalam cawan petri steril lalu dituang media VRB cair dan dihomogenkan dengan cara menggeserkan horizontal atau membentuk angka delapan. Agar dibiarkan 
memadat. Setelah memadat, dituang kembali 3 sampai $4 \mathrm{~mL}$ media VRB cair diatas permukaan agar (overlay) dan diinkubasikan pada suhu $35-37{ }^{\circ} \mathrm{C}$ selama 24-48 jam. Koloni koliform yang dihitung adalah koloni yang berwarna merah keunguan yang dikelilingi oleh zona merah.

\section{Konfirmasi Koliform}

Pilihlah koloni-koloni yang mewakili semua jenis koloni yang tumbuh. Ambillah 10 koloni dengan ose steril, dan pindahkan masing-masing ke dalam $10 \mathrm{~mL} \mathrm{BGLBB}$ steril dalam tabung-tabung reaksi yang telah dilengkapi dengan tabung durham. Inkubasikan tabung-tabung reaksi tersebut pada suhu $35{ }^{\circ} \mathrm{C}$ selama 24-48 jam, amati terbentuknya gas dalam tabung durham sebagai reaksi positif. Hitunglah tabung yang berisi gas. Untuk meyakinkan pertumbuhan koliform, buatlah preparat ulas dari tabung positif yang diwarnai pewarnaan Gram.

$$
\text { Tabungan posiif }(\%)=\frac{\text { Jumlah tabungan positif }}{10} \times 100 \%
$$

Jumlah koliform per $\mathrm{mL} /$ gram $=\%$ tabung positif $\times$ jumlah (seluruh) koloni dalam cawan petri $\times$ faktor pengenceran cawan petri tersebut.

\section{Uji konfirmasi Escherichia coli dengan metoda the Most Probable Number (MPN)}

Tabung (seri 3) yang berisi EC broth yang dilengkapi dengan tabung Durham. Tabung BGLB positif digoyang secara hati-hati dan dengan ose steril dipindahkan suspensi ke masing-masing seri tabung reaksi berisi EC broth, disesuaikan dengan pengencerannya. Selanjutnya diinkubasi pada suhu $45.5^{\circ} \mathrm{C}$ selama 48 jam. Amati terbentuknya gas sebagai reaksi positif setelah diinkubasikan selama 24 jam. Bila belum terbentuk gas, inkubasi dilanjutkan dan amati reaksi positif pada 48 jam. Jumlah tabung yang positif dari masing-masing seri dicocokkan dengan tabel statistik untuk mengetahui jumlah fecal coliform, dan dinyatakan dengan MPN per unit sampel. Dengan ose steril pindahkan suspensi dari masing-masing tabung positif ke Leviness eosinmethylen blue (L-EMB) agar dan goreskan ke permukaan agar beberapa kali agar dapat diperoleh koloni tunggal. Inkubasikan cawan pada suhu $35^{\circ} \mathrm{C}$ selama $18-24$ jam dan amati adanya koloni berwarna gelap dan datar dengan atau tanpa warna metal. 2 koloni yang dicurigai dipindahkan dari tiap cawan L-EMB ke agar miring PCA untuk pengujian morfologi dan biokimia, kemudian inkubasikan pada suhu $35^{\circ} \mathrm{C}$ selama $18-24$ jam. Selanjutnya dilakukan pewarnaan Gram, dan diamati adanya bakteri coccus atau cocoid, Gram negatif. Uji konfirmasi E. coli dilanjutkan ke uji biokimia IMViC (Indol-Voges Proskauer-Methyl red-Citrat) sebagai berikut:

a. Produksi Indole: tabung berisi tryptone broth dan diinkubasi pada suhu $35{ }^{\circ} \mathrm{C}$ selama 24 jam. Reagent Kovacs sebanyak 0.2-0.3 mL untuk menguji adanya pembentukan indole yang ditunjukkan dengan adanya warna merah yang jelas di bagian atas.

b. Voges-Proskauer: Inokulasi tabung berisi MRVP broth dan inkubasikan pada suhu $35^{\circ} \mathrm{C}$ selama 48 jam. Suspensi sebanyak $1 \mathrm{~mL}$ dimasukkan ke dalam tabung berukuran $13 \times 100 \mathrm{~mm}$. Larutan alpha-naphthol sebanyak $0.6 \mathrm{~mL}$ dan $\mathrm{KOH} 40 \%$ sebanyak sebanyak $0.2 \mathrm{~mL}$ kemudian dikocok. Setelah itu ditambahkan beberapa kristal kreatin, dikocok lagi dan diamkan selama 2 jam. Uji positif ditunjukkan dengan terbentuknya warna pink eosin.

c. Methyl red: Setelah test VP, inkubasikan lagi tabung MRVP pada suhu $35^{\circ} \mathrm{C}$ selama 48 jam. Larutan methyl red sebanyak 5 tetes ditambahkan ke masing-masing tabung. Positif test ditunjukkan dengan adanya warna merah yang jelas. Sedangkan reaksi negatif ditunjukkan dengan adanya warna kuning.

d. Citrate: Inokulasi secara ringan tabung yang berisi Koser citrate broth; hindari adanya kekeruhan yang dapat terdeteksi dengan jelas. Inkubasikan pada suhu $35^{\circ} \mathrm{C}$ selama 9 jam. Adanya kekeruhan yang jelas menunjukkan reaksi positif.

e. Pembentukan gas dari fermentasi laktosa: Inokulasi tabung berisi LST broth dan inkubasikan pada suhu 35 ${ }^{\circ} \mathrm{C}$ selama 48 jam. Reaksi positif ditunjukkan dengan berpindahnya media dari tabung bagian dalam atau timbulnya busa setelah dilakukan agitasi secara halus.

f. Interpretasi: Semua kultur yang 1) memfermentasikan laktosa dengan produksi gas pada suhu $35^{\circ} \mathrm{C}$ dalam 48 jam, 2) muncul sebagai bakteri coccus, Gram negatif, dan 3) mempunyai pola ++-- (biotipe 1) atau -+-- (biotipe 2) pada uji IMViC dinyatakan sebagai $E$. coli. Hitung MPN E. coli berdasarkan tabung-tabung EC yang mengandung E. coli yang berasal dari 3 konsentrasi yang berurutan.

\section{Uji Reduktase (Methylen blue reduction test)}

Uji reduktase dilakukan dengan cara memasukkan ke dalam tabung reduktase steril $1 \mathrm{~mL}$ larutan biru metilen dan ditambahkan sampel susu sampai batas lingkar. Tabung ditutup menggunakan sumbat, lalu dihomogenkan dengan cara membolak-balikkan tabung (+ 3 kali) sampai warna biru tersebar merata. Tabung dimasukkan ke dalam inkubator, masukkan dulu tabung dalam penangas air $\left(37+1{ }^{\circ} \mathrm{C}\right)$ selama 5 menit untuk menghangatkan baru dimasukkan ke dalam inkubator. Pembacaan hasil dapat dimulai minimal setelah $2 / 3$ dari warna sudah berubah menjadi putih. Sebaiknya reaksi ditunggu sampai seluruh warna biru hilang. Hasil uji dinyatakan dalam satuan waktu, dimana waktu reduksi (angka reduktase) menunjukkan waktu yang dibutuhkan sejak saat memasukkan tabung kedalam inkubator/penangas air bersuhu $37{ }^{\circ} \mathrm{C}$ sampai seluruh warna biru hilang (Sudarwanto 2012).

\section{Nilai pH}

$\mathrm{pH}$ susu kambing pasteurisasi diukur dengan menggunakan pH meter (merk Jenway model 3520).

\section{Analisis Statistik}

Penelitian ini menggunakan Rancangan Acak Lengkap (RAL) dengan perlakuan lama penyimpanan, yaitu P1 (kontrol/penyimpanan 0 hari), P2 (penyimpanan 12 hari), P3 (penyimpanan 24 hari), P4 (penyimpanan 36 hari), P5 (penyimpanan 48 hari), P6 (penyimpanan 60 hari) dan dengan ulangan sebanyak 3 kali sehingga terdapat 18 unit percobaan. Data yang diperoleh dari pengujian mikrobiologi dan sifat fisik susu kambing pasteurisasi dianalisis dengan 
analysis of varian (ANOVA) menggunakan software Statistical Package for The Social Sciences (SPSS) versi 21.

\section{HASIL DAN PEMBAHASAN}

Hasil penelitian tehadap jumlah TPC, S. aureus, koliform dan E. coli susu kambing pasteurisasi disajikan pada Tabel 1. Hasil analisis sidik ragam (Tabel 1) menunjukkan bahwa susu kambing pasteurisasi dengan perlakuan penyimpanan 0 hari, 12 hari, 24 hari, 36 hari, 48 hari, dan 60 hari tidak berpengaruh nyata $(\mathrm{P}>0.05)$ terhadap TPC. Walau secara statistik tidak menunjukan perbedaan antar perlakuan tetapi terdapat peningkatan jumlah mikroorganisme pada perlakuan penyimpanan hari ke-24 sampai dengan hari ke60. Peningkatan TPC pada setiap perlakuan dikarenakan proses pasteurisasi suhu $71-75{ }^{\circ} \mathrm{C}$ selama 15 detik hanya dapat mengurangi $95-96 \%$ jumlah mikroba awal pada susu (Fox dan Cameron 1989; Soeparno 2011).

Tabel 1. Rataan jumlah TPC, S. aureus, koliform dan E. coli susu kambing pasteurisasi pada penyimpanan berbeda

\begin{tabular}{lcccc}
\hline \multirow{2}{*}{ Perlakuan } & \multicolumn{4}{c}{ Jumlah Mikroba (log cfu/mL) } \\
\cline { 2 - 5 } & TPC & S. aureus & Koliform & E. coli \\
\hline $\begin{array}{l}\text { Penyimpanan } \\
0 \text { hari }\end{array}$ & 2.00 & 0 & 0 & 0 \\
$\begin{array}{l}\text { Penyimpanan } \\
12 \text { hari }\end{array}$ & 2.00 & 0 & 0 & 0 \\
$\begin{array}{l}\text { Penyimpanan } \\
24 \text { hari }\end{array}$ & 2.79 & 0 & 0 & 0 \\
$\begin{array}{l}\text { Penyimpanan } \\
36 \text { hari }\end{array}$ & 3.50 & 0 & 0 & 0 \\
$\begin{array}{l}\text { Penyimpanan } \\
48 \text { hari }\end{array}$ & 3.99 & 0 & 0 & 0 \\
$\begin{array}{l}\text { Penyimpanan } \\
60 \text { hari }\end{array}$ & 4.37 & 0 & 0 & 0 \\
\hline Rataan & 3.11 & 0 & 0 & 0 \\
\hline
\end{tabular}

Mikroba yang masih bertahan didalam susu pasteurisasi adalah bakteri yang bersifat termodurik antara lain dari genus Bacillus, Micrococcus, Microbacterium, Streptococcus, Lactobacillus, Corynebacterium, Streptococcus, dan Arthobacter (Sudarwanto 2012). Bakteri termodurik ini tidak segera mati pada pasteurisasi (Soeparno 2011) dan akan memengaruhi jumlah bakteri susu pasteurisasi tergantung dari populasinya dalam susu segar atau sebelum pasteurisasi (Sudarwanto 2012; Wulandari et al. 2017), sedangkan bakteri thermophilic tidak berkembang dalam waktu yang singkat pada proses HTST (Soeparno 2011). Penyimpanan pada suhu refrigerator $\left(4-10^{\circ} \mathrm{C}\right)$ mampu menekan pertumbuhan bakteri termodurik yang masih bertahan didalam susu pasteurisasi dikarenakan bakteri ini hidup pada suhu $20-37{ }^{\circ} \mathrm{C}$. TPC pada lama penyimpanan hari ke-60 terus bertambah, hal ini kemungkinan karena adanya pertumbuhan bakteri yang bersifat psikotrofik Gram negatif mengontaminasi susu setelah proses pasteurisasi. Bakteri psikrotrofik yang banyak ditemukan adalah genus Pseudomonas, Flavobacterium,
Alcaligenes dan beberapa koliform lainnya. Kerusakan susu pasteurisasi terjadi apabila jumlah Gram negatif psikrotrofik lebih dari $10^{6}$ per mL (Sudarwanto 2012).

Susu kambing pasteurisasi yang masih memenuhi syarat SNI 01-3951 (BSN 1995) berdasarkan jumlah TPC adalah pada penyimpanan hari ke-60 yaitu $4.37 \log \mathrm{cfu} /$ mL. SNI 01-3951 mensyaratkan batas maksimum cemaran TPC pada susu pasteurisasi adalah $4.48 \log \mathrm{cfu} / \mathrm{mL}$. Hal ini menunjukkan bahwa susu kambing yang dipasteurisasi pada suhu $71-75^{\circ} \mathrm{C}$ selama 15 detik yang dikemas dengan botol plastik dan disimpan pada suhu refrigerator dengan kisaran suhu antara 4 dan $10^{\circ} \mathrm{C}$ masih layak dikonsumsi berdasarkan jumlah TPC sampai dengan penyimpanan 60 hari.

Bakteri S. aureus (Tabel 1) tidak ditemukan pada susu kambing yang telah dipasteurisasi pada suhu $72{ }^{\circ} \mathrm{C}$ selama 15 detik sampai dengan penyimpanan hari ke-60. Bakteri $S$. aureus merupakan bakteri komensal yang biasa terdapat diambing dan lingkungan. Bakteri ini merupakan salah satu penyebab penyakit mastitis yang dapat menyerang kambing perah. Bakteri ini dapat dimusnahkan dengan suhu pemanasan seperti pasteurisasi. Keberadaan bakteri $S$. aureus dalam susu pasteurisasi biasanya terjadi akibat kontaminasi setelah pemanasan (Wanniatie dan Hanum 2015; Wanniatie et al. 2019). Apabila $S$. aureus mengontaminasi setelah pemanasan maka bakteri ini mampu hidup dengan cepat karena bakteri ini dapat berkembang dengan cepat bila tidak ada bakteri lainnya. Bakteri ini dapat membahayakan karena dapat menghasilkan toksin yang dapat mengganggu kesehatan konsumen yang mengonsumsi susu.

Tabel 1 menunjukkan bahwa proses pasteurisasi pada suhu $72{ }^{\circ} \mathrm{C}$ selama 15 detik dapat menginaktifkan bakteri koliform dan E. coli dan dengan lama penyimpanan sampai dengan 60 hari pada suhu penyimpanan $4-10{ }^{\circ} \mathrm{C}$ (suhu refrigerator) mampu menekan pertumbuhan bakteri tersebut. Bakteri koliform dan E. coli merupakan bakteri termodurik yang berasal dari ternak terutama faecal dan lingkungan yang dapat mencemari susu (Suwito 2010). Bakteri ini dapat diinaktifkan dengan cara pemanasan salah satunya dengan proses pasteurisasi pada suhu $72{ }^{\circ} \mathrm{C}$ selama 15 detik.

Bakteri koliform hampir selalu ditemukan pada susu segar, tetapi dengan metode produksi yang baik salah satunya dengan pasteurisasi, jumlah bakteri koliform dapat dipertahankan rendah bahkan bisa mati (Salman dan Hamad 2011). Apabila jumlah awal bakteri koliform tinggi makan proses pasteurisasi tidak mampu untuk mematikan seluruh bakteri koliform. Penelitian Cahyaningtyas et al. (2016) menunjukkan bahwa susu pasteurisasi yang disimpan pada suhu refrigerator mulai mengalami peningkatan pada hari ke-14. Adanya bakteri koliform dapat menyebabkan kerusakan pada susu pasteurisasi bila suhu pasteurisasi tidak tepat dan penyimpanan susu pasteurisasi tidak dilakukan dengan benar (Salman et al. 2013; Umar et al. 2014)

E. coli biasanya dijadikan sebagai mikroba indikator. E. coli merupakan mikroba yang berasal dari saluran pencernaan manusia dan hewan. Bakteri ini dijadikan bakteri indikator dikarenakan $E$. coli dapat bertahan hidup didalam air dibandingkan bakteri patogen lainnya (Sudarwanto 
2012). E. coli termasuk bakteri patogen yang biasanya dianjurkan diperiksa untuk produk susu pasteurisasi.

Susu kambing yang dipasteurisasi pada suhu $72{ }^{\circ} \mathrm{C}$ selama 15 detik dengan perlakuan penyimpanan pada suhu refrigerator $\left(4-10^{\circ} \mathrm{C}\right)$ selama $0,12,24,36,48$, dan 60 hari berdasarkan analisis sidik ragam (Tabel 2) menunjukkan bahwa tidak berpengaruh nyata $(\mathrm{P}>0.05)$ terhadap reduktase dan nilai $\mathrm{pH}$ susu. Angka reduktase dijadikan pengujian jumlah kuman secara langsung dengan melihat perubahan warna susu yang dari biru menjadi putih kembali akibat kemampuan mikroba mereduksi methylene blue. Waktu reduksi tidak selalu ditentukan oleh jumlah mikroorganisme (bakteri), tetapi penanganan susu yang sangat memengaruhi waktu reduksi. Apabila susu segera disimpan pada suhu rendah setelah pemerahan, maka waktu reduksi akan diperpanjang. Hal ini disebabkan karena suhu rendah akan menghambat perkembangan jumlah mikroorganisme, terutama kelompok mikroorganisme asam laktat (lactic acid bacteria) (Sudarwanto 2012).

Tabel 2. Rataan angka reduktase dan $\mathrm{pH}$ susu kambing pasteurisasi pada penyimpanan berbeda

\begin{tabular}{lcl}
\hline \multicolumn{1}{c}{ Perlakuan } & $\begin{array}{c}\text { Angka Reduktase } \\
\text { (jam) }\end{array}$ & $\mathrm{pH}$ \\
\hline Penyimpanan 0 hari & 7.17 & 6.76 \\
Penyimpanan 12 hari & 8.00 & 6.98 \\
Penyimpanan 24 hari & 8.00 & 6.93 \\
Penyimpanan 36 hari & 7.17 & 6.67 \\
Penyimpanan 48 hari & 7.00 & 6.86 \\
Penyimpanan 60 hari & 4.67 & 6.60 \\
\hline Rataan & 7.00 & 6.80 \\
\hline
\end{tabular}

Semakin cepat perubahan warna yang terjadi, maka diasumsikan semakin banyak jumlah mikroba di dalam susu pasteurisasi. Semakin lama masa penyimpanan susu kambing pasteurisasi maka semakin banyak mikroba yang tumbuh di dalam susu kambing pasteurisasi tersebut (Pusparini dan Kentjonowaty 2015). Tabel 2 menunjukkan bahwa pada perlakuan penyimpanan 60 hari (P6) susu pasteurisasi mampu direduksi mikroba dalam waktu 4.67 jam. Hal ini menunjukkan bahwa kualitas susu termasuk dalam kelas I (Sudarwanto 2012), sedangkan menurut Soeparno (2015) apabila perubahan warna kurang dari 6 jam, tetapi tidak kurang dari 2 jam termasuk klasifikasi susu kelas tiga (fair).

Laju reduksi juga dipengaruhi jenis mikroorganisme. Koliform adalah bakteri yang paling cepat mereduksi warna biru metilen (Soeparno 2015), tetapi berdasarkan pengujian mikroorganisme, tidak ditemukan koliform didalam susu kambing pasteurisasi (Tabel 1). Apabila tidak ditemukan koliform, maka kerusakan susu dapat disebabkan oleh Streptococcus lactis, beberapa Streptococcus dari faecal, dan Micrococcus tertentu (Soeparno 2015). Kenaikan jumlah mikroba yang ditandai dengan kecepatan waktu yang dibutuhkan mikroba pada uji reduktase sesuai dengan TPC pada penelitian ini. Nilai TPC pada penyimpanan 60 hari (P6) adalah $4.37 \mathrm{log} \mathrm{cfu} / \mathrm{mL}$ dan angka reduktase adalah $4.67 \mathrm{jam}$.
Nilai $\mathrm{pH}$ pada penyimpanan 0 sampai dengan 60 hari tidak terdapat perbedaan. Penurunan $\mathrm{pH}$ terjadi pada penyimpanan hari ke-60 tetapi tidak siginifikan. $\mathrm{pH}$ mengalami penurunan apabila ada aktifitas mikroba jenis bakteri asam laktat (BAL) yang mampu merubah laktosa menjadi asam, sehingga suasana susu menjadi asam. $\mathrm{pH}$ pada penelitian berkisar antara 6.60-6.98. Kisaran angka tersebut merupakan $\mathrm{pH}$ yang ideal bagi pertumbuhan banyak mikroorganisme. Sebagian besar mikroorganisme mempunyai $\mathrm{pH}$ optimum netral kira-kira 6.0-7.5 (Soeparno 2015). Susu kambing pasteurisasi penyimpanan 60 hari (P6) pada permukaan bagian atas susu ditemukan kapang. Diduga mikroba yang berkembang pada susu pasteurisasi yang disimpan pada suhu refrigerator pada penelitian ini adalah bukan golongan mikroba yang membentuk asam. Kapang dan khamir merupakan mikroba yang dapat merusak susu pasteurisasi pada suhu penyimpanan refrigerator. Kapang dan khamir dapat tumbuh pada lemak (krim) susu yang terdapat dipermukaan susu (bagian atas) dan pada kondisi sedikit asam karena dapat tumbuh pada $\mathrm{pH}$ yang lebih luas.

\section{KESIMPULAN}

Susu kambing yang dipasteurisasi dengan metode HTST (suhu $72{ }^{\circ} \mathrm{C}$ selama 15 detik) masih layak dikonsumsi sampai dengan penyimpanan 60 hari. Hal ini ditandai dengan kualitas mikrobiologi (TPC, S. aureus, koliform, E. coli) masih dibawah batas cemaran mikroba pada SNI 01-3951-1995 yaitu berturut-turut $4.37 \log \mathrm{cfu} / \mathrm{mL}, 0,0,0$, dan didukung dengan nilai angka reduktase 7.00 jam dan $\mathrm{pH} 6.8$.

\section{UCAPAN TERIMA KASIH}

Penelitian ini terlaksana dengan bantuan pendanaan dari Hibah BLU Fakultas Pertanian Universitas Lampung.

\section{DAFTAR PUSTAKA}

BSN (Badan Standardisasi Nasional). 1995. SNI 01-39511995 tentang Susu Pasteurisasi. Jakarta (ID): BSN.

BSN (Badan Standarisasi Nasional). 1998. SNI 012782:1998: Metoda Pengujian Susu Segar. Jakarta (ID): BSN.

Cahyaningtyas, A. A., W. Pudjiastuti \& I. Ramdhan. 2016. Pengaruh suhu penyimpanan terhadap organoleptik dan pertumbuhan bakteri koliform pada susu pasteurisasi. J Riset Teknologi Industri. 10(1):1323.

Chotiah, S. 2020. Beberapa bakteri patogen yang mungkin dapat ditemukan pada susu sapi dan pencegahannya. Semiloka Nasional Prospek Industri Sapi Perah menuju Perdangan Bebas.

Fox, B. A. \& A. G. Cameron. 1989. Food Science, Nutrition, and Health. 5th Ed. Edward Arnold. London.

Pusparini, O. R. \& I. Kentjonowaty. 2018. Pengaruh lama simpan pada refrigerator terhadap kualitas susu kambing pasteurisasi. Dinamika Rekasatwa. 8(1):4144.

Salman, A. M. A. \& I. M. Hamad. 2011. Enumeration and 
identification of Coliform bacteria from raw milk in Khartoum State Sudan. J. Cell Anim. Biol. 5(7):121128.

Salman, A. M. A., Eltaf, \& M. Hagar. 2013. Some bacterial and physical quality of pasteurized milk in Khartoum. J. Apllied and Industrial Scienc 1(2):30-37.

Sudawanto, M. 2012. Buku Pegangan: Pemeriksaan Susu dan Produk Olahannya. IPB Press, Bogor.

Soeparno. 2015. Properti dan Teknologi Produk Susu. Gadjah Mada University Press, Yogyakarta.

Suwito, W. 2010. Bakteri yang sering mencemari susu: Deteksi, pathogenesis, epidemiologi, dan cara pengendaliannya. Jurnal Litbang Pertanian 29(3):96100.

Umar, Razali, \& A. Novita. 2014. Derajat keasaman dan angka reduktase susu sapi pasteurisasi dengan lama penyimpanan yang berbeda. J. Medika Veterinaria. 8(1):43-46.
Wanniatie, V. \& Z. Hanum. 2015. Kualitas susu pasteurisasi komersil. Agripet. 15(2):92-97.

Wanniatie, V., M. B. Sudarwanto, T. Purnawarman, \& A. Jayanegara. 2019. Comparison of microbiological quality between organic and conventional goat milk: A study case in Bogor, Indonesia. Adv. Anim. Vet. Sci. 7(7): 593-598.

Walkling-Ribeiro, M., O. Rodriguez-Gonzalez, S. Jayanam, \& M. W. Griffiths. 2011. Microbial inactivation and shelf life comparison of "cold" hurdle processing with pulsed electric fields and microfiltration, and conventional thermal pasteurization in skim milk. Int. J. Food Microbiol. 144(3):379-386.

Wulandari, Z., E. Taufik, \& M. Syarif. 2017. Kajian kualitas produk susu pasteurisasi hasil penerapan rantai pendingin. JIPTHT 05(3):94-100. 